\title{
Aerodynamic parameters of windbreak based on its optical porosity
}

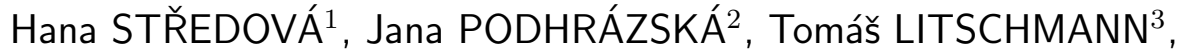 Tomáš STŘEDA ${ }^{4}$, Jaroslav ROŽNOVSKÝ ${ }^{5}$}

${ }^{1}$ Department of Applied and Landscape Ecology, Mendel University in Brno Zemědělská 1, 61300 Brno, Czech Republic; e-mail: hana.stredova@mendelu.cz

${ }^{2}$ Research Institute for Soil and Water Conservation

Lidická 25/27, 60200 Brno, Czech Republic; e-mail: podhrazska.jana@vumop.cz

${ }^{3}$ AMET

Žižkovská 1230, 69102 Velké Bílovice, Czech Republic; e-mail: amet@email.cz

${ }^{4}$ Department of Crop Science, Breeding and Plant Medicine, Mendel University in Brno Zemědělská 1, 61300 Brno, Czech Republic; e-mail: streda@mendelu.cz

${ }^{5}$ Czech Hydrometeorological Institute, Brno - Branch Office

Kroftova 43, 61667 Brno, Czech Republic; e-mail: roznovsky@chmi.cz

\begin{abstract}
The paper summarizes the results of wind velocity measurement in different distances from windbreak in combination with optical porosity (OP) determination in different periods. Experimental data were obtained by direct measurement of wind speed and OP analyses of images of four windbreaks in Southern Moravia (part of Czech Republic). Wind speed at $2 \mathrm{~m}$ above the soil surface in a defined distance from windbreak had been measured since 2006. Thirty images of different phenological stages of selected windbreaks from 2006 to 2010 were analyzed. Windward or leeward images were converted into black and white spectrum. All available measurements were used for a map creation. The highest values of OP (up to 50\%) are achieved in non-vegetation period. Due to the high OP variability in height of terminal tree branches "OP reduced" was also assessed (just squares to $2 / 3$ height of windbreaks were evaluated). The wind speed reduction on the leeward side relatively strongly correlated with OP value. The highest correlation was found out when the wind speed measurement at $50 \mathrm{~m}$ on leeward side was used. The dependence decreases with increasing distance. Full foliage in summer $(10 \%$ $\mathrm{OP}$ ) reduces a wind speed about $60 \%$ at $50 \mathrm{~m}$ and about $30 \%$ at $150 \mathrm{~m}$ on the leeward. These values for non-foliaged windbreaks decrease to 80 and $90 \%$. Maximum distance of windbreak effect on wind speed reduction was found out by the extrapolation of the curves constructed using the regression equation of wind speed reduction in dependence on OP and different distances from the windbreak. Regardless of OP value, the reduction effect disappears at a distance of $250 \mathrm{~m}$. The quietest zone of evaluated windbreak with an average height of windbreaks $15-18 \mathrm{~m}$ was detected in the area about four times the height $(4 \mathrm{H})$. The effect of windbreaks decreases with increasing porosity.
\end{abstract}

Key words: optical porosity, windbreak, wind speed 


\section{Introduction}

Windbreaks have been used for many years to reduce wind speed as a winderosion control measure. However, it is still not clear what should be an optimal design for windbreaks. Aerodynamics and erosion control parameters of windbreaks are variable regarding to wood species, density and rows number. On the basis of windbreak testing (each with different stem and canopy porosity and number of rows) on their efficiency in wind-speed reduction, conclusions given below were found out. Evenly distributed porosity of stem and canopy resulted in the longest protected area. Dense lower parts were more efficient than more porous lower parts. Erosion was almost not observed in the case of a barrier with evenly distributed porosity. The absence of a dense lower part resulted in an excessive zone of erosion behind the barrier (Cornelis et al., 2000). In term of permeability and efficiency windbreaks are classified into wind porous, wind medium porous and nonporous (Abel et al., 1997). Windbreaks alter horizontal wind speed, turbulence and vortex airflow. Height and porosity of windbreaks are two major controls on these airflows and both are amenable to design and management (Forman, 1995).

Actual shape of wind speed curve depends mainly on height and porosity of windbreak and additionally on other important characteristics of airflow $\times$ windbreak system (i.e. on characteristics of incoming flow such as wind speed, wind direction, turbulence intensity and atmospheric stability and on external characteristics of the windbreaks, such as windbreaks shape, width and length (Vigiak et al., 2003). Significantly variable aerodynamic properties of deciduous trees during the year must be taken into account.

The aerodynamic porosity of the windbreak determines the ratio between airflow that passes through the barrier pores ("through-flow") and airflow that diverges over the barrier ("diverged-flow"). It is impractical, at least throughout the landscape, to physically measure the aerodynamic porosity of natural tree windbreaks (Loeffler et al., 1992).

The impact of individual windbreaks on air flow in its vicinity (in the vertical and horizontal profiles) can be described by the methods that allow simple expression of windbreak aerodynamic properties during the year. An analysis of optical porosity (OP) of the windbreak allows assessing its effect in different phenological phases. 
The method is based on computer analysis of digital images and windbreaks. OP is defined as the ratio between the gaps in windbreaks to its total area (Guan et al., 2003). OP is expressed as a remainder to value 1 or in percents as a remainder to 100 percent. Decreasing OP means increased windbreak efficiency and its protective function. An impact of OP in different contexts was quantified by Fu et al. (1992), Loeffler et al. (1992), Groß (1993), Jiang et al. (1994), Zhu et al. (2003).

Most papers referring to OP method do not contain its exact description but just a general information. For example according to Sudmeyer and Scott (2002) the OP is a ratio of the windbreak area trough which the sky is visible in frontal view to the total windbreak area. The individual sections were assessed by planimeter from contrasting black and white photographs. The main disadvantage of this method is a conversion and reduction of $3 \mathrm{D}$ space to 2D space (Loeffler et al., 1992).

Procedure for OP determination applicable to our conditions was published by Litschmann and Rožnovský (2005). They described the detailed assessments of OP for each vertical layer of windbreaks to define OP changes with height. Litschmann et al. (2007) described OP assessment in vertical and horizontal direction. In this case, the windbreak area was covered by grid-network and OP was determined for each square. This concept was then used with some modifications by Mužiková and Jareš (2010) and Mužíková et al. (2010).

Wan et al. (2005) found out a significant correlation between windbreak porosity, number of rows and row spacing. Forman (1995) presents that highly porous windbreak, such as a row of planted poplars (Populus) decreases wind speed only minimally, but it has the advantage of also minimizing turbulence. Furthermore a highly porous windbreak provides a relatively long distance of reduced airflow downwind, although wind speed is only slightly slower than wind in the open. Low-porosity windbreak produces a short downwind zone of highly diminished wind speed and high levels of turbulence. Medium-porous windbreak has the wind speed reduction nearly as great as the impenetrable barrier.

In frame of field measurements Grant and Nickling (1998) evaluated a vegetation drag coefficient to optimal management of windbreak and its function modeling. They found out the highest vegetation drag coefficient when optical porosity was about $20 \%$ and volume porosity about $50 \%$. 
Decreasing porosity below $20 \%$ does not further increase the extent of shelter. Several wind tunnel trials indicate that the optimal extent of shelter is provided by windbreaks with $20 \%$ porosity (Burke, 1998). Ian et al. (2009) determined for practical uses that porosity did determine wind speed and the degree of shelter is roughly similar to windbreak density i.e. a windbreak with $30 \%$ porosity would reduce wind speed to $70 \%$ of the open-field speed at the most sheltered location.

The paper summarizes the results of wind velocity measurement in different distances from windbreak in combination with OP determination in different periods. The procedure is suitable for relatively rapid assessment of the windbreak efficiency. It can be applied in erosion control measures realization in frame of land adjustment or for revitalizing of existing windbreaks. The obtained results could be successfully used in landscape and urban planning.

\section{Materials and methods}

\section{Experimental windbreaks:}

Experimental data were obtained by direct measurement of wind speed and OP analyses of images of four windbreaks in southern Moravia: municipalities of Micmanice (MC), Suchá Loz (SL), Dolní Dunajovice (DD) and the Blatnice pod Svatým Antonínkem (BS). Windbreaks in Moravian countryside were planted in the fifties to sixties in 20th century with subsequent insufficient maintenance and management. Main woods are mostly Populus $\times$ euroamericana and Fraxinus excelsior L. Additional trees are mostly Tilia cordata Mill. and Acer negundo L. Height of individual windbreaks varies from 12 to 25 meters, width from 12 to $20 \mathrm{~m}$. Surrounding of windbreaks is used for intensive agricultural cultivation. The windbreaks are described in detail by Litschmann et al. (2007).

\section{Measurement of wind speed:}

Wind speed at $2 \mathrm{~m}$ above the soil surface in a defined distance from windbreak has been measured since 2006. The wind speed and direction were measured by anemometers type W1 (TM Prague) and W2 (TM Prague). Anemometers were regularly calibrated in the Czech Hydrometeorological 
Institute (CHMI) laboratory. Six anemometer sets measured at the distances of 150 and 50 meters from the windbreaks on the windward side and at 50,100, 150 and $200 \mathrm{~m}$ on leeward side. The measurements were realized when wind was blowing perpendicular to the windbreaks and average wind speed exceeded $2 \mathrm{~m} . \mathrm{s}^{-1}$. Measurements were carried out before and after the main crop growing season or during the growing season to a maximum plant height of $10 \mathrm{~cm}$. The duration of measurement was about 2 hours. Instantaneous wind speed from each anemometer was recorded in a separate data logger in 5 second step.

\section{Optical porosity:}

Thirty images of different phenological stages of selected windbreaks from 2006 to 2010 were analyzed. Windward or leeward images were always taken from the same point at a distance of $30 \mathrm{~m}$. The images were converted into black and white spectrum, divided into 9 to 11 vertical columns and 7 to 9 horizontal lines. The precision and spatial distribution of OP determination increases with the number of squares. OP of each square was assessed by ImageTool analyses. The resulting OP for each image was then determined as the arithmetic average of all squares.

\section{Graphic and statistical expression:}

Reduction of air velocity at different distances from the windbreaks and at different optical porosity was expressed by $2 \mathrm{D}$ contour map. The input data and mapping output were carried out by program Surfer ver.8.03, local polynomial interpolation method, polynomial order 2nd. All available measurements (from all selected windbreaks) were used for a map creation.

Reduction of wind speed in dependence on OP and the distance from the windbreaks were expressed by multiple linear regression method in STATISTICA ver.7 software. The relationship between two independent variables (OP and the distance from the windbreaks) and the dependent variable (reduction of wind speed) was quantified by quadratic regression equations.

\section{Results and discussion}

Optical porosity, relative wind speed at distance of 50, 100 and $150 \mathrm{~m}$ on the leeward side and at $150 \mathrm{~m}$ on the windward side $(100 \%)$ in terms of 
individual measurements are given in Table 1.

The OP was assessed as "OP total" (for the whole height of the windbreaks) and due to the high OP variability in height of terminal tree branches as well as "OP reduced" (just squares to $2 / 3$ height of windbreaks were evaluated).

Table 1. OP values and reduction of relative wind speed on the leeward side compared with wind speed at $150 \mathrm{~m}$ on the windward side

\begin{tabular}{|c|c|c|c|c|c|}
\hline $\begin{array}{l}\text { Term of the } \\
\text { measurement }\end{array}$ & $\begin{array}{l}\text { OP total } \\
(\%)\end{array}$ & $\begin{array}{c}\text { OP reduced } \\
(\%)\end{array}$ & $\begin{array}{c}\text { Speed at the } \\
\text { distance of } 50 \mathrm{~m} \\
(\%)\end{array}$ & $\begin{array}{c}\text { Speed at the } \\
\text { distance of } 100 \\
\text { m (\%) }\end{array}$ & $\begin{array}{c}\text { Speed at the } \\
\text { distance of } 150 \mathrm{~m} \\
(\%)\end{array}$ \\
\hline \multicolumn{6}{|c|}{ Suchá Loz } \\
\hline 18.4 .2007 & 52 & 50 & 83 & 87 & 99 \\
\hline 24.4 .2009 & 32 & 31 & 61 & 59 & 68 \\
\hline 11.11 .2007 & 43 & 37 & 55 & 67 & 83 \\
\hline \multicolumn{6}{|c|}{ Dolní Dunajovice } \\
\hline 19.4 .2006 & 32 & 30 & \begin{tabular}{|l|}
68 \\
\end{tabular} & 79 & 90 \\
\hline 5.5 .2008 & 18 & 13 & 40 & 58 & 75 \\
\hline \multicolumn{6}{|c|}{ Micmanice } \\
\hline 4.5 .2006 & 20 & 19 & 36 & 46 & 74 \\
\hline 11.10 .2006 & 21 & 15 & 45 & 56 & 59 \\
\hline \multicolumn{6}{|c|}{ Blatnice } \\
\hline 31.10 .2010 & 31 & 27 & 52 & 58 & 73 \\
\hline
\end{tabular}

Overview of the analyzed image and $\mathrm{OP}$ value in individual terms are given in Fig. 1. The highest values of OP (up to 50\%) are logically achieved in non-vegetation period. Almost full foliage of windbreaks occurs in approximately 10 days in the spring. The OP is changing analogically (from values typical for the winter to values of full foliage). Autumn leaf fall lasts longer and a gradual change of OP is longer. Although two values of OP (vegetation and non-vegetation) for each windbreak can be considered. Transitional periods are very short and their timing is given by weather conditions of the particular year.

The combination of wind speed reduction and OP total and OP reduced for all evaluated windbreaks and measurements is shown in Fig. 2 and Fig. 3. The wind speed reduction on the leeward side is relatively strongly correlated with OP value (especially when using OP reduced value). The highest correlation was found when the wind speed measurement at $50 \mathrm{~m}$ on leeward side was used. The dependence decreases with increasing distance and influence of other factors on the air flow is more significant. Full foliage in 


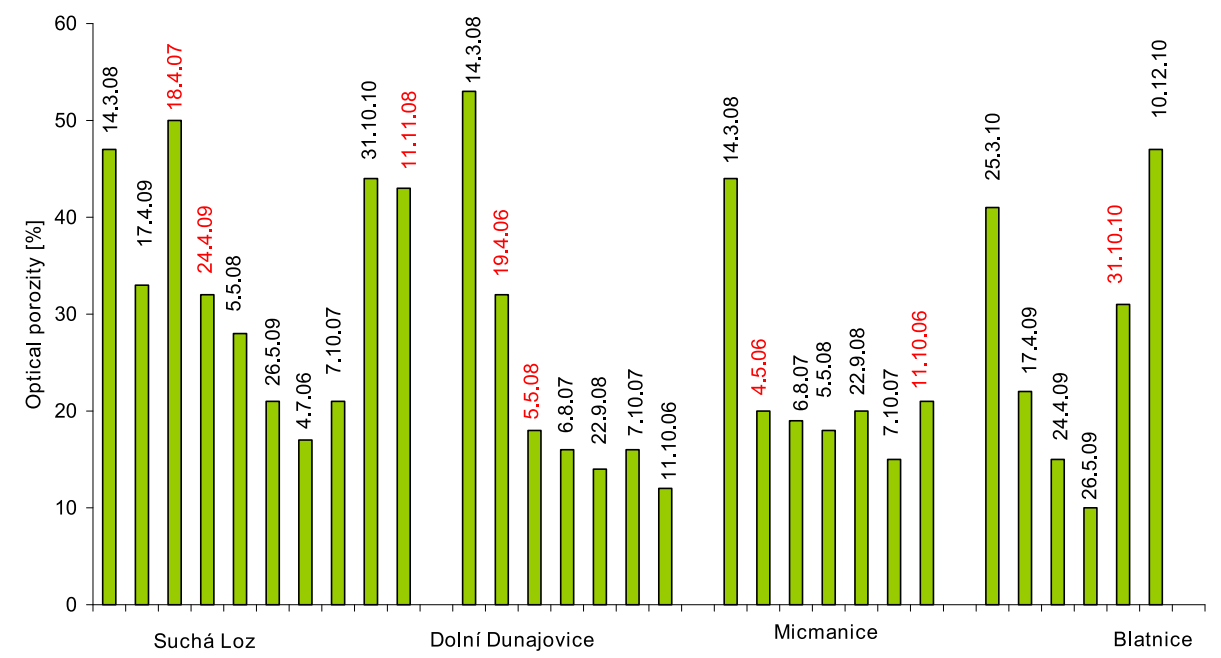

Fig. 1. Comparison of OP values during the vegetation (wind speed profile was simultaneously measured as shown by red).

summer $(10 \%$ OP) reduces a wind speed about $60 \%$ at $50 \mathrm{~m}$ and about $30 \%$ at $150 \mathrm{~m}$ on the leeward side in comparison with speed at $150 \mathrm{~m}$ on the windward side. These values for non-foliaged windbreaks decrease to 80 and $90 \%$.

The curves shown in Fig. 4 were constructed using the regression equation of wind speed reduction in dependence on OP and different distances from the windbreaks. The wind speed reduction on the leeward side for individual OP values can be derived from the curves. Maximum distance of windbreak effect on wind speed reduction was determined by the curves extrapolation. Regardless of OP value the reduction effect disappears at a distance of $250 \mathrm{~m}$. Marshall (1967) defined the maximum wind speed reduction about $60 \%$ approximately at a distance of four times height of windbreak. An average altitude of windbreaks in the SL, DD, MC and BS 15 to $20 \mathrm{~m}$ means this distance from 60 to $80 \mathrm{~m}$. Caborn (1957) observed minor speed reduction on the leeward side even at a distance of 30 multiple of its height $(30 \mathrm{H})$. Practical effect (reduction of wind speed at least about $20 \%$ ) is achieved at a maximum distance of 15 to $20 \mathrm{H}$.

The main task of analyzed windbreaks is a protection against wind ero- 


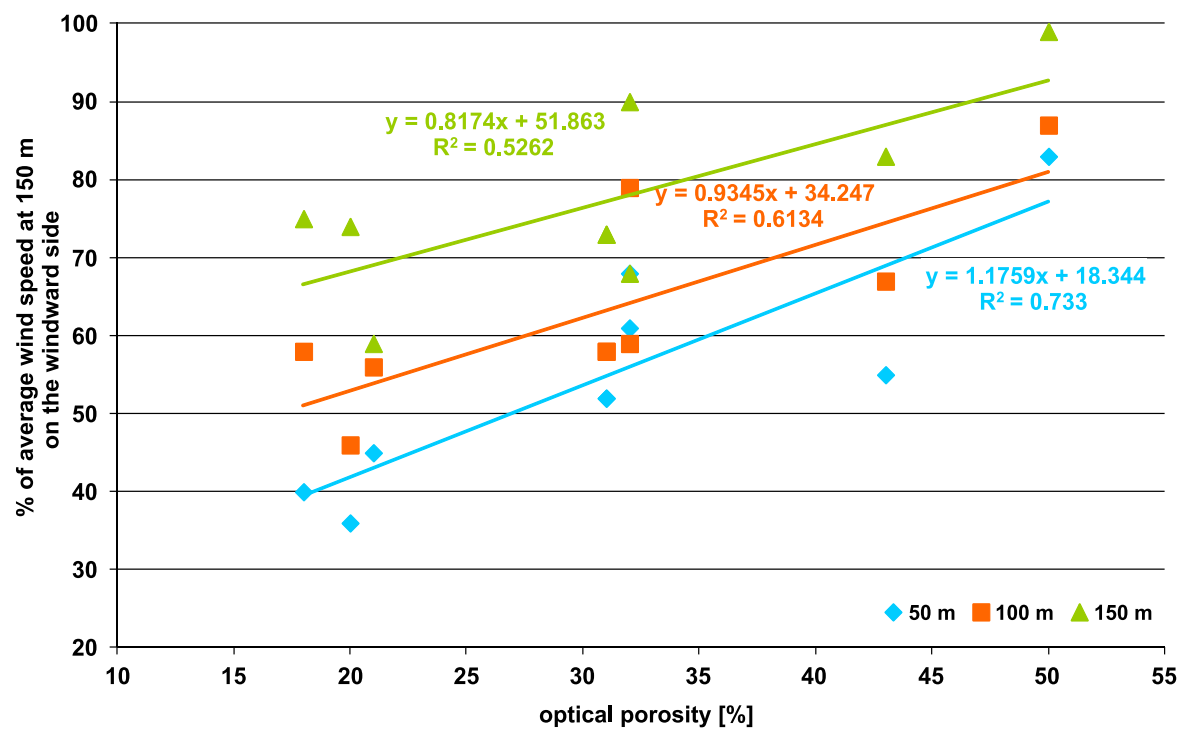

Fig. 2. Influence of OP on wind speed reduction on the leeward side - OP total.

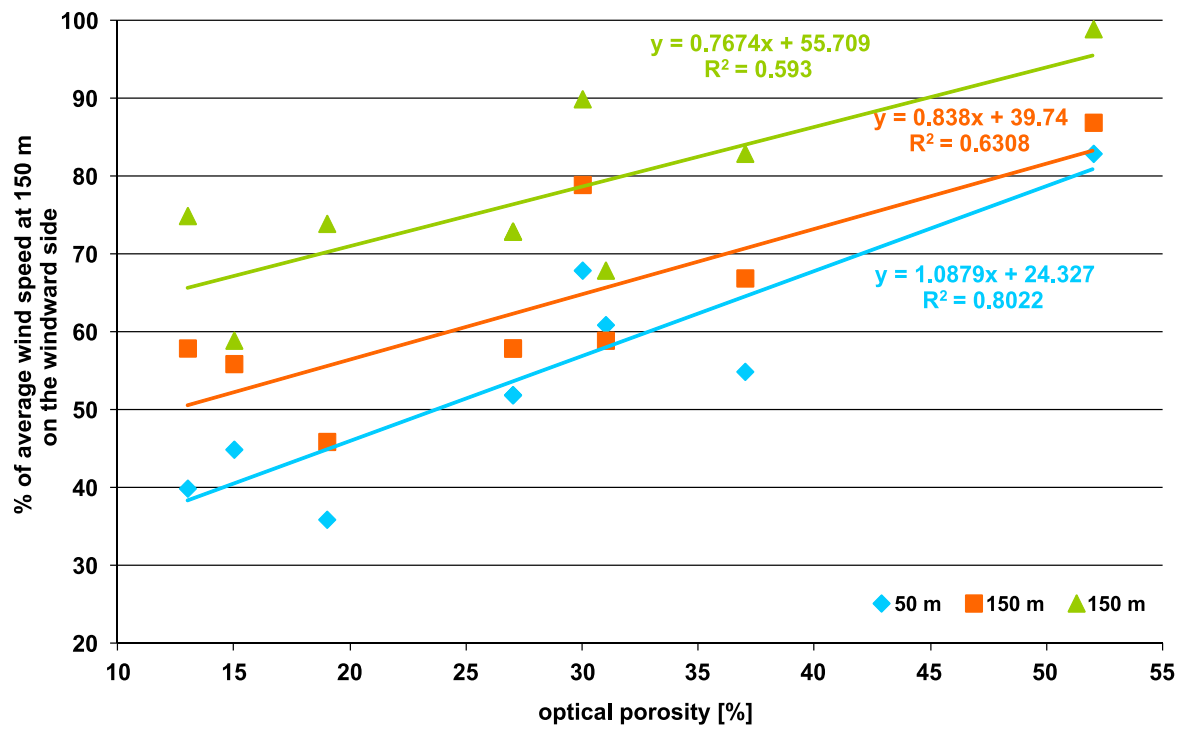

Fig. 3. Influence of OP on wind speed reduction on the leeward side - OP reduced. 


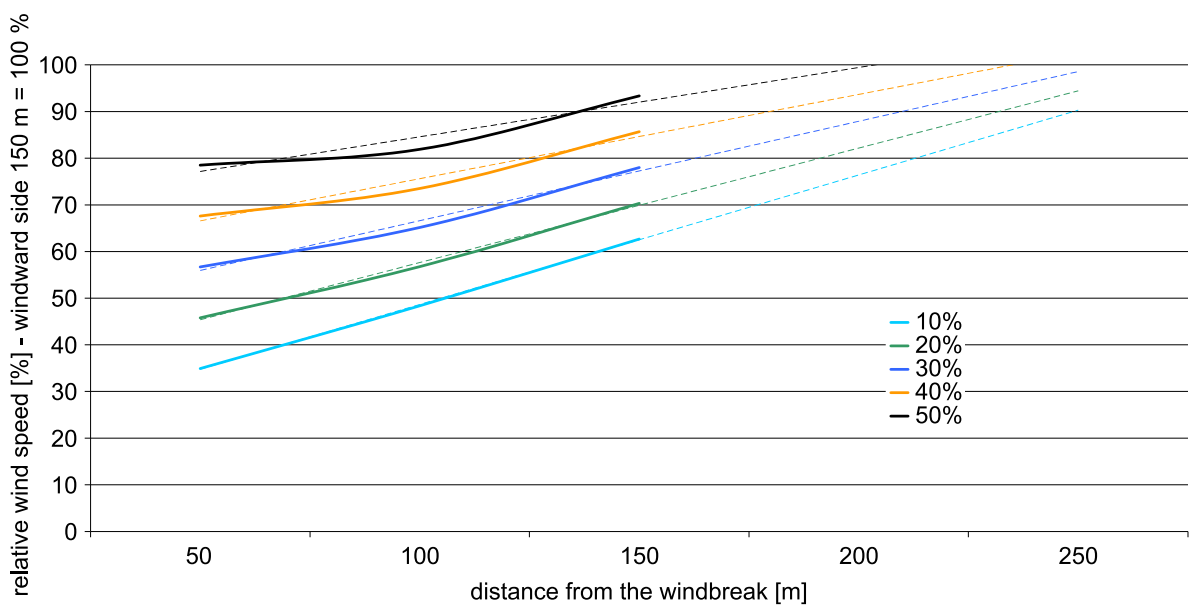

Fig. 4. Wind speeds reduction at different distances on the leeward side of windbreaks depending on OP.

sion. Therefore their effect in the autumn and spring seasons (i.e. when higher OP values) is the most significant. Effectiveness of windbreaks in this critical period can be particularly enhanced by evergreen trees planting. Windbreaks with conifers are able to not only protect the area against erosion, but also from cold winds in winter, i.e. when deciduous windbreaks show reduced efficiency (Straigh and Brandle, 2007).

Wind speed reduction by windbreak of different OP is expressed in Fig. 5 by $2 \mathrm{D}$ maps created in Surfer program. The application provides a userfriendly output with a simple determination of the wind speed reduction based on the OP and the distance from the windbreaks. Surfer is primarily mapping software, which provides only graphical output. A regression equation of used interpolation method is therefore not provided. Figure 5 indicates the highest wind speed reduction at a distance of about 50-60 meters on the leeward side.

According to De Sy (2009) a quiet zone forms in the lee of the windbreak. It has a triangular shape with the boundaries formed by the windbreak, the ground surface, and a line sloping downwards from the top of the windbreak. This line intersects the ground between 3 and $8 \mathrm{H}$ downwind of the windbreak. In the quiet zone the minimum wind speed occurs, and turbu- 
lent eddies are smaller and less energetic than in the approach airflow.

The quietest zone of evaluated windbreak with an average height of windbreaks $15-18 \mathrm{~m}$ was detected in the area about $4 \mathrm{H}$. The effect of windbreaks decreases with increasing porosity. The results therefore fully correspond with other authors - maximum wind speed reduction between $2 \mathrm{H}$ and $8 \mathrm{H}$ (depending on porosity) and $80 \%$ recovery of the upwind wind speed around 20H (Cleugh, 2003; Cleugh, 1998; Hagen, 1991 and Hagen, 1995 in Vigiak et al., 2003; Bird et al., 2007; Ian et al., 2009).

Relationship between OP and the distance from windbreak as well as their effect on the wind speed reduction was defined by multiple regression with a quadratic polynomial interlaying of fifth grade with usage of software STATISTICA:

$\mathrm{Z}=46.1894+0.1709 \mathrm{X}-0.4606 \mathrm{Y}-0.0008 \mathrm{X}^{2}-0.0004 \mathrm{XY}-0.000094226 \mathrm{Y}^{2}$,

where:

$\mathrm{Z}$ - wind speed reduction $(\%)$

$\mathrm{X}$ - distance from the windbreak $(\mathrm{m})$

$\mathrm{Y}$ - optical porosity (\%)

Figure 6 presents a verification of model quality compared with real measured data. Determination Index of 0.664 and low values dispersion outside the $99 \%$ confidence interval indicate a relatively good agreement between modeled and real data. 67 data sets (distance from windbreak and OP versus the wind speed reduction) obtained from measurement of four structurally different windbreaks were used for the validation.

\section{Conclusion}

The paper evaluates the wind speed reduction by windbreak on the basis of OP assessment. The method allows quantifying the influence of windbreaks of different structures in different phenological stages without the need of direct terrain measurements. Computer analysis of digital photographs of the two pheno-phases is sufficient for the evaluation (in the case of larger or heterogeneous windbreaks more images might be needed).

The described method is applicable for the line windbreaks (up to tens 


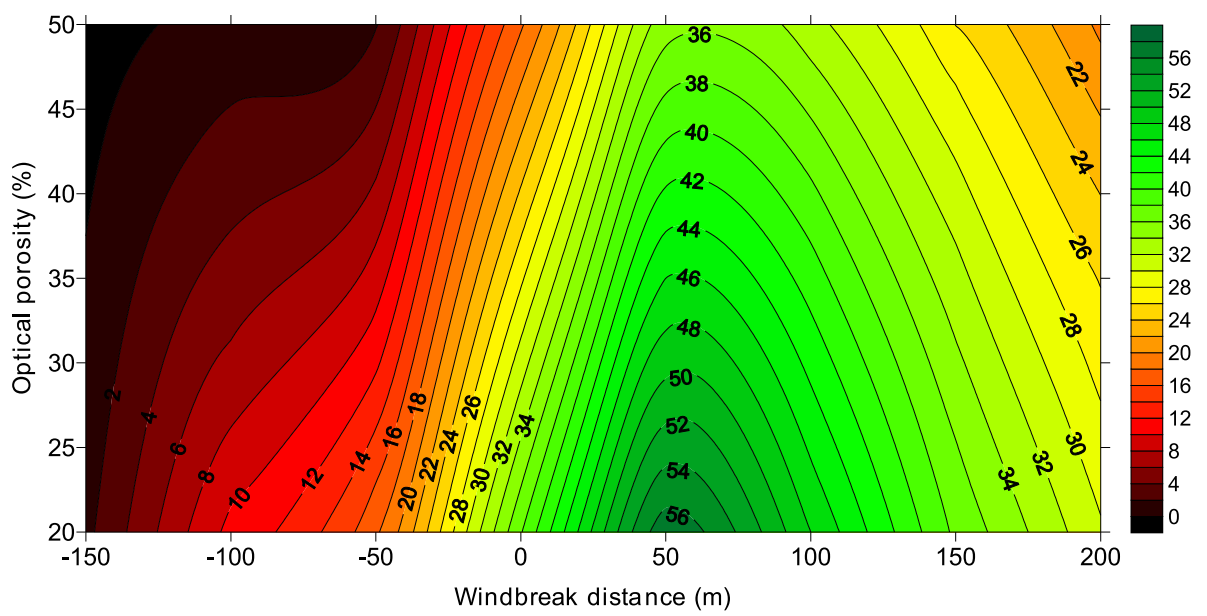

Fig. 5. Wind speed reduction (in \%) at different distances from the windbreak depending on the OP.

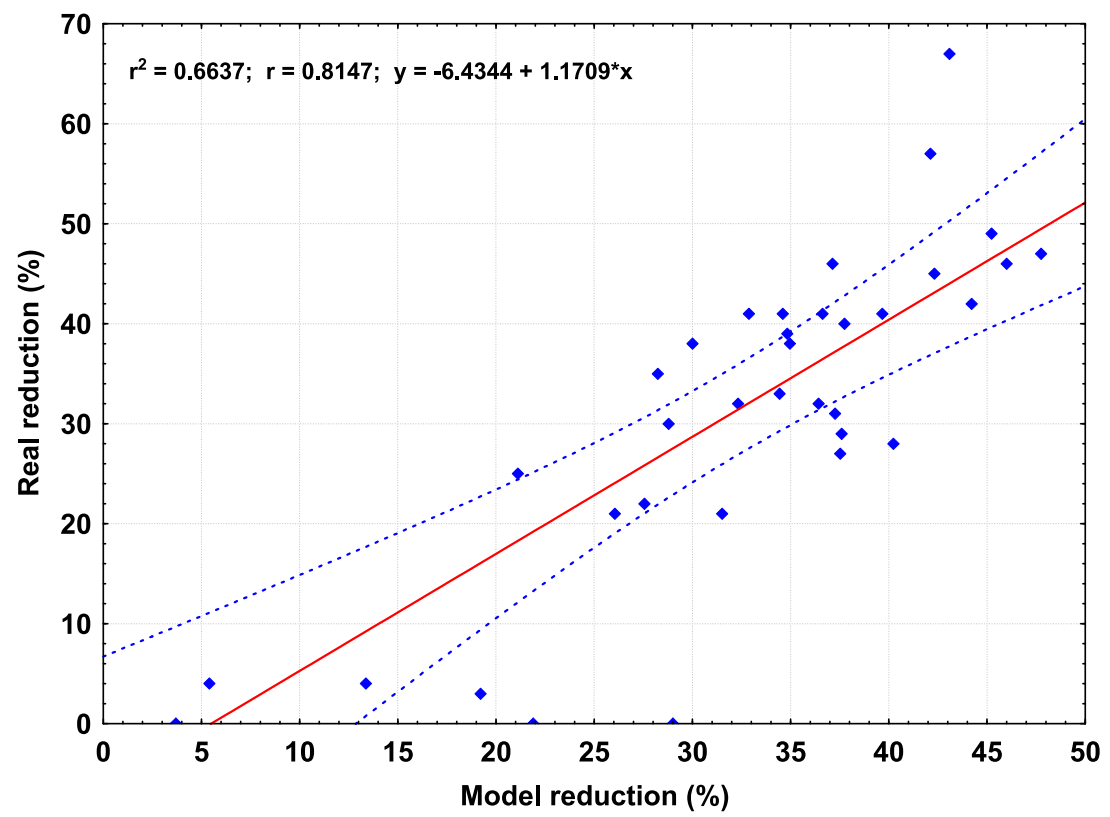

Fig. 6. Comparison of wind speed reduction based on the model output compared with measured values. 
meters wide) and requires high-resolution images (Kenney, 1987 and Jiang et al., 1989). In the case of wider windbreaks the relationship between spaces of possible air circulation (aerodynamic porosity) and spaces permeable for the light (optical porosity) is no longer valid. The optical porosity is less than the real porosity and the difference is the highest for the wide shelterbelt (Lindholm et al., 1988). Mutual occultation of individual plant parts on two-dimensional images causes almost near-zero optical porosity, despite the actual existence of three-dimensional air circulation spaces (among others Torita and Satou, 2007). Aerodynamic porosity of windbreaks wide 12 to 20 meters can still be successfully evaluated by the optical porosity method.

The relationship between OP and the wind speed reduction is the strongest at the distance of the first measurement (i.e. at $50 \mathrm{~m}$ ). The relationship is reduced with increasing distance due to other factors. The relationship between $\mathrm{OP}$ and the wind speed reduction is higher when just lower $2 / 3$ of windbreak is used for OP assessment (OP reduced). When evaluating the entire height of windbreaks (OP total) some errors caused by complicated pixel resolution of sparse crown and sky can occur. The relationship between $\mathrm{OP}$ and wind speed reduction at different distances on the leeward side proved the full foliage windbreak influence even at a distance of 200 to $250 \mathrm{~m}$. For the bare windbreaks this distance is only about $50 \mathrm{~m}$. When increasing the number of rows a positive effect could only be observed close to the windbreak. From a distance of about $10 \mathrm{H}$ single-row windbreaks with evenly distributed porosity were most effective in reducing wind speed (Cornelis et al., 1999).

Acknowledgments. This research was supported by project of the Ministry of Agriculture NAZV QH82099 "Criteria of wind erosion expansion on heavy-textured soils and possibilities of its limitation with biotechnological control measurements"

\section{References}

Abel N., Baxter J., Campbell A., Cleugh H., Fargher J., Lambeck R., Prinsley R., Prosser M., Reid R., Revell G., Schmidt C., Stirzaker R., Thorburn P., 1997: Design principles for farm forestry: A guide to assist farmers to decide where to place trees and farm plantations on farms. Barton, A.C.T.: Rural Industries Research and Development Corporation, Canberra, 102 p. 
Bird P. R., Jackson T. T., Kearney G. A., Roache A., 2007: Effects of windbreak structure on shelter characteristics. Australian journal of experimental agriculture, 47, 6, $727-737$.

Burke S., 1998: Windbreak characteristics. In Windbreaks. Inkata Press, Port Melbourne, Victoria, Australia, p. 5.

Caborn J. M., 1957: Shelterbelts and microclimate. Edinburgh University, Bulletin, 29, Forestry commission, $136 \mathrm{p}$.

Cleugh H., 1998: Effects of windbreaks on airflow, microclimates and crop yields. Agroforestry systems, 41, 55-84.

Cleugh H., 2003: Trees for shelter: a guide to using windbreaks on Australian farms. Joint venture agroforestry program, rural industries research and development corporation. Barton, A.C.T.: Rural Industries Research and Development Corporation, Canberra, $70 \mathrm{p}$.

Cornelis W. M., Gabriels D., Lauwaerts T., 1999: Simulation of windbreaks for winderosion control in a wind tunnel. Proceedings of Wind Erosion, Manhattan, USA, 1999, 8 p.

Cornelis W. M., Gabriels D., De Gryse S., Hartmann R., 2000: The efficiency of vegetative windbreaks in combating wind erosion: simulation and scaling. Science et changements planétaires / Sécheresse, 11, 1, 52-57.

De Sy V., 2009: Spatial modeling of windbreak effects on wind erosion in South Patagonia, Argentina. Master thesis Land Degradation and Development Group. Wageningen University, $60 \mathrm{p}$.

Forman R. T. T., 1995: Land mosaic: the ecology of landscapes and regions. Cambridge University Press, Cambridge, UK, 182-184.

Fu M. H., Jiang F. Q., Yang R. Y., 1992: Study on porosity of poplar shelterbelts and its application in belts tending felling. In: Jiang F. Q. (ed). Management techniques and theoretical basics for shelterbelts. Chinese Forestry Press, Beijing, 102-108 (in Chinese with English abstract).

Grant P. F., Nickling W. G., 1998: Direct field measurement of wind drag on vegetation for application to windbreak design and modelling. Land Degradation and Development, 9, 57-66.

Groß G., 1993: Numerical simulation of canopy flows. Springer-Verlag, Berlin, Heideberg, Now York, London, Paris, Tokyo, Hong Kong, Barcelona, Budapest, 166 p.

Guan D., Zhang Y., Zhu T., 2003: A wind-tunnel study of windbreak drag. Agricultural and forest meteorology, 118, 1-2, 75-84.

Hagen L. J., 1991: A wind erosion prediction system to meet user needs. Journal of Soil and Water Conservation, 46, 106-111.

Hagen L. J., 1995: WEPS technical documentation: erosion submodel. WEPP/WEPS Symposium. Soil andWater Conservation Society, Ankeny, USA.

Ian N., Brendan G., Reid R., 2009: Aerodynamic and microclimate changes behind windbreaks. In Agroforestry for natural resource management. CSIRO Publishing, Collingwood, Australia, p. 78. 
Jiang F. Q., Xu J. Y., Fu M. H., Liu Z. G., 1989: Determination of shelterbelt porosity by digital image processing. In: Xiang K. F. (ed). Protective plantation technology. Publishing house of Northeast Forest University, Harerbin, 366-370 (in Chinese with English abstract).

Jiang F. Q., Zhou X. H., Fu M. H., Zhu J. J., Lin H. M., 1994: Shelterbelt porosity model and its application. Chinese Journal of Applied Ecology, 5, 251-255 (in Chinese with English abstract).

Kenney W. A., 1987: A method for estimating windbreak porosity using digitized photographic silhouettes. Agricultural and Forest Meteorology, 39, 91-94.

Lindholm G., Kristenson E., Nilsson K., 1988: Viixrer som vindskydd (Vegetation for shelter). Stad \& Land, 62, Alnarp (in Swedish).

Litschmann T., Rožnovský J., 2005: Optical porosity of windbreak and its influence on wind character. In: Rožnovský J., Litschmann T. (ed): "Bioclimatology of the present and future", Křtiny 12.-14.9. 2005 (in Czech).

Litschmann T., Rožnovský J., Podhrázská J., 2007: Using of optical porosity to windbreak classification, In: Střelcová K., Škvarenina J., Blaženec M. (eds.): Bioclimatology and natural hazards. International Scientific Conference, 14.-20. September, Polana nad Detvou, Slovakia (in Czech).

Loeffler A. E., Gordon A. M., Gillespie T. J., 1992: Optical porosity and windspeed reduction by coniferous windbreaks in southern Ontario. Agroforestry Systems, 17, $2,119-133$.

Marshall J. K., 1967: The effect of shelter on the productivity of grasslands and field crops. Field Crops Abstr., 20, 1, 1-14.

Mužíková B., Jareš V., 2010: Seasonal variability of windbreak affectivity and their optical porosity. MendelNet 2010, Proceedings of International Ph.D. Students Conference, Brno, 24.11.2010, 412-426 (in Czech).

Mužíková B., Toman F., Jareš V., 2010: Partial study of windbreak effect on wind speed reduction. 18th International Poster Day Transport of Water, Chemicals and Energy in the Soil-Plant-Atmosphere System, Bratislava, 11.11.2010 (in Czech).

Straight R., Brandle J., 2007: Windbreak density: Rules of thumb for design. Agroforestry notes, USDA, $4 \mathrm{p}$.

Sudmeyer R. A., Scott P. R., 2002: Characterisation of a windbreak system on the south coast of western Australia. Microclimate and wind erosion. Australian Journal of Experimental Agriculture, 42, 6, 703-715.

Torita H., Satou H., 2007: Relationship between shelterbelt structure and mean wind reduction. Agricultural and Forest Meteorology, 145, 3-4, 186-194.

Vigiak O., Sterk G., Warren A., Hagen L. J., 2003: Spatial modeling of wind speed around windbreaks. Catena, 52, 273-288.

Wan M., Pan C., Wang M., Jin Y., 2005: Application of the digitized measurement on windbreak porosity of farmland shelter-forests. Arid Land Geography, 28, 1, $120-123$.

Zhu J., Gonda Y., Matsuzaki T., Yamamoto M., 2003: Modeling relative wind speed by optical stratifi cation porosity within the canopy of a coastal protective forest at different stem densities. Silva Fennica, 37, 2, 189-204. 